\title{
Consequences of climate change in agriculture and ways to cope up its effect in Nepal
}

\author{
Mina Nath Paudel \\ National Agriculture Genetic Resource Center, Khumaltar
}

Email: mnpaudel@gmail.com

\begin{abstract}
Nepal is one of the four most vulnerable countries affected by climate change in the world. Climate change has been occurred in Terai, hills and mountain of Nepal resulting change in agriculture systems. Global food production of major staples crops of rice, maize, wheat and soybean, and marine resources are decreasing. Nepal is blessed with number of natural flora and fauna which could address negative impact of climate change resulting food and nutritional insecurity. Emphasis should be given to develop technologies address negative impact of climate change. Nepal has been trying to develop some adoptive ways such as development of climate resilient technology encompassing crop varieties, animal breeds; agronomic practices that could address vagaries of climate change and sustain food and nutritional security. In Nepal, the effect of climate change is more pronounced in hills and mountains with respect to increase in temperature than that of Terai. In this paper, bird's eye views on issues of climate change, negative impact of climate change on food and nutritional security and coping mechanisms to tackle all of such concerns of climate change in agriculture in general and food and nutritional security in particular have been illustrated in ways climate change could be addressed to limit its negative consequences on agriculture as well.
\end{abstract}

Key words: climate change, adaptation, global agriculture, food security

\section{Background}

Nepal lies in coordinates of $28^{\circ} \mathrm{N}$ and $84^{\circ} \mathrm{E}$ and it is situated in between China in the north and India, in the east, west and south. In Nepal, broadly, there are five geographical regions; the Himalaya, high hills, mid-hills, Siwalik and, and Terai. However, agroecologically, it is divided into (hills both high and mid), Siwalik and Terai. Nepal, noted for her majestic Himalayas, the roof of the world, Sagarmatha, Mount Everest (8848m) in the north and the lowest point Kechanakal $(60 \mathrm{~m})$ in the south. The Himalayas, the water towers, which supply water to the Indo-gangetic plain of Indian subcontinent, are the proud of the mountainous and hilly country, Nepal. Nepal is about 650 kilometers long and about 200 kilometers wide, and comprises a total of 147,181 square kilometers area. Climate of Nepal varies from cool summers and severe winters in north to subtropical summers and mild winters in south. 
Nepal is primarily divided into five major physiographic regions which run in more or less parallel bands from northwest to southeast. Each of these regions has a distinctive agricultural and forestry land utilization pattern. These regions are known as the Himalaya, high mountains, middle mountains, Siwalik, and Terai. Hills and mountains are adversely affected due to global warming and anthropogenic activities of humans far from these areas. The impact of global warming has been experienced in the Himalaya regions that had resulted permafrost thinning and formation of glacial lakes in the Himalaya regions.

\section{Methodology}

Ten years' meteorological data of Kakani high hills) and Dhangadhi (Terai) have been analysed for temperature ( $\mathrm{T}$ min and $\mathrm{T} \max$ ), rainfall (total and number of rainy days) in both site. Data were interpreted by using graphs. Extensive information has been collected with respect to crop varieties released by research institute to address effect of climate change in Nepal. Detailed collection of secondary information has been documented using print and electronic media whichever available.

\section{Results and discussion}

\section{Climate change and Nepal}

Climate change has been observed in Nepal in varying level of climates that are prevalent in diversified topography and vegetation (Paudel, 2010, 2012). There are impacts of climate changes in Terai, mid-hills and valley (subtropical region), and mountains and the Himalaya (temperate and tundra regions) of Nepal. It was reported that the pioneer mountaineer Mr. Apa Sherpa, the Goodwill Ambassador to Climate Change (Sherpa, 2010) scaled Mount Everest for the $21^{\text {st }}$ time on 11 May 2011 and observed that there was no snow on the Everest trail and he waited snow fall for days at the base camps to scale Mt. Everest. Apa on 23 May 2010 noticed stream flowing on top of the Everest by melting ice (Shrestha, 2009). A country like Nepal could not explain more than this as the impact of climate changes in the Himalayan region. Because of climate change it is reported untimely start of monsoonal rainfall that resulted rain deficit in the eastern Terai lowlands in 2005/06, reducing crop production by $12.5 \%$ nationwide (Malla, 2008). In agriculture, about $10 \%$ of agricultural land was left fallow due to rain deficit on the one hand, while on the other hand in the midwestern Terai faced heavy rain with floods, which reduced crop production by 30\% (Regmi, 2007). Adverse effect of climate change could lead to the extinction of some indigenous crop varieties such as many aromatic rice varieties including Basmati rice,

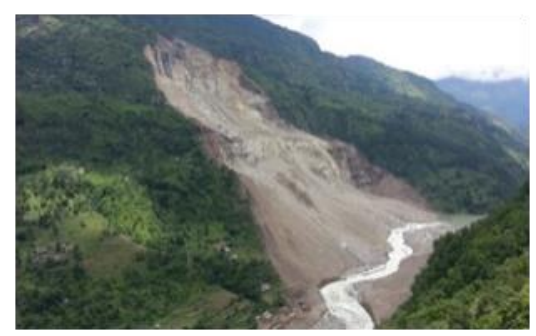

Fig. 1 Landslide by the Sunkoshi River in 2014 
some local wheat, maize, and other agricultural crops as well (Paudel, 2012). It was also observed that a severe winter cold wave in Nepal in 1998 had negative impacts on agricultural productivity and showed a high percentage of yield reduction for potato (27.8\%), leaf mustard (36.5\%), mustard seed (11.2\%), lentil (37.6\%), and chickpea (38\%) (NARC $1987 / 88$ to $1997 / 98$ ).

In Nepal, negative impacts of climate change are observed for food crops which are already infected by diseases and pests such as club root of crucifiers, blight of solaneceous, rust of wheat, blast of rice and leaf spot of maize and red ants which have become menace leading to decreasing crop productivity. Issues of climate change should be addressed timely. By doing so there are possibilities of coping climate change with respect to food security and poverty reduction to meet the MDGs set by the UN for 2015 for developing countries (Paudel, 2010). In recent past, almost every year, Nepal has been facing an unpredictable effect of climate change in the form of flood, landslide, drought, untimely onset and exhaust of monsoon. Consequently there has been heavy toll of human, animals and vegetation. In August, 14, 2014, land slide in the Sunkoshi river brought misery losses of agriculture land and human settlements (Fig.1 ) in Nepal. This land slide killed 33 people and 122 were reported still missing. Experts say this event, one of the deadliest in the country's recent history, is a wake-up call for hazard mapping, early warning, and disaster management (http://www.irinnews.org/country/npa/nepal). This land slide checked flow of the Sunkoshi River and created havoc in downstream and the Government of Nepal declared emergency in the downward settlement areas of river bank until the flow of water was made normal from the army rescue. There are other cases of such devastation in the Hindu Kush mountain regions and similar other mountain regions across the world which justify impact of climate change due to heavy and untimely down pour. Thus, it is imperative that climate change is intensifying existing problems including excessive rain in some places and reduced rain in other places, runoff and increased heat stress, recurrent drought and floods, heavy loss of lives, loss of rural livelihood, and food insecurity. Bates et al (2008) have reported high rate of glacial melt due to increases in in temperature accelerating the rate of such incidents increased between 1950s and 1990s from 0.38 to 0.54 events per year.

Table 1 depicts the impact of climate change from 2030 to 2090 with respect to change in temperature and precipitation resulting in runoff (Bartlett et al; 2010). Bartlett et al (2010) portrays the impacts of climate change on temperature and precipitation triggering runoff in the $21^{\text {st }}$ century in Nepal. This is very much an alarming situation for Nepal where majority of population depends on farming for livelihood. It is, therefore, fundamental for Nepalese leaders, planners, and resource manager to think very urgently and decisively to begin national plan of adaptation to climate change. 
Table 1. Bartlett et al (2010) have anticipated climate change impact in Nepal for temperature, precipitation and runoff as given below:

\begin{tabular}{|c|c|}
\hline Temperature & $\begin{array}{l}\text { - Significant rise in temperature }\left({ }^{0} \mathbf{c}\right) \\
\circ \quad 0.5 \text { to } 2 \text { by the } 2030 \\
\circ \quad 1.3 \text { to } 3.8 \text { by the } 2060 \\
\circ 1.8 \text { to } 5.8 \text { by the } 2090 \\
\text { - Increased in the number of days and nights considered hot by current } \\
\text { standards } \\
\text { - Highest temperature increase during the months of June to August at } \\
\text { high elevations }\end{array}$ \\
\hline Precipitation & 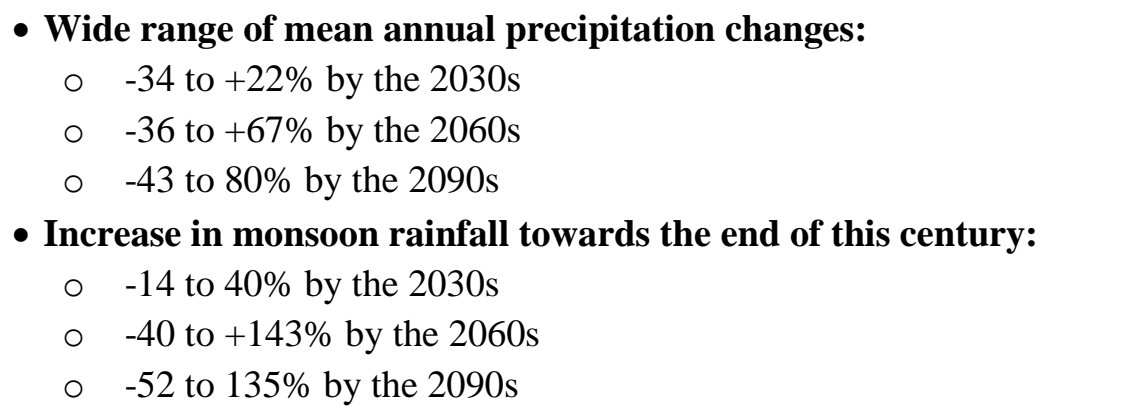 \\
\hline Runoff & $\begin{array}{l}\text { - Higher downstream flows in the short term but lower stream flows in } \\
\text { the long term due to retreating glacier and snow melt and ice melt } \\
\text { - Shift from snow to rain in winter months } \\
\text { - Increased extreme events including floods, droughts and GLOFs }\end{array}$ \\
\hline
\end{tabular}

\section{Effect of climate change in high hills and Terai of Nepal}

Nepal ranks the fourth most climate-vulnerable countries in the world and is highly exposed to a range of water related hazards such as floods, droughts and landslides (https://unfccc.int/files/adaptation/application/pdf/nepal_summary_cca.pdf, http://www. worldbank.org/en/news). In December 2009, a cabinet meeting of the Council of Minister of the Government of Nepal $(\mathrm{GoN})$ was held at the base of the Everest. A 10-point 'Everest Declaration' of the cabinet includes developing communities' capacity to cope up with climate change and working together with other countries to mitigate the impact of global warming (Shrestha, 2009) in the Cop 15 to begin $15^{\text {th }}$ December 2009. The declaration also supported developed countries' plans to contribute $1.5 \%$ of GDP to a climate fund and bring down greenhouse gases to pre-industrialization levels. Year round snow caped Himalayas including the Mount Everest in Nepal have experienced impact of climate change thereby immense glacier retreat in the Himalayan region. Had the Himalayan peaks are devoid of snow what would be the fate of rivers flowing from those mighty water towers, the Himalayas? The Himalayas are responsible to supply water to the perennial rivers flowing in the Indo-Gangetic, the Mekong, and Tibetan plateaus. 
Ultimately, Europe and the entire Asia-Pacific region would be affected immediately and in the long run the impact would be for the entire earths' civilization and the climate as a whole. Hence, there is no question of victimizing from the impact of climate change for a single country like Nepal whose contribution on global climate change is negligible (around $0.02 \%$ ); i.e., miniscule compared to developed and industrialized countries (Paudel, 2010).

To know the impact of climate change in Nepal two places (Kakani of Nuwakot district and Dhangadhi of kailali district) were selected to compare 10 years' meteorological data (temperature, total rainfall and number of rainy days) in Nepal as shown in Fig 2 and 3 (Paudel, 2015). Kakani, central high hills (2030m) and Dhangadhi, in far western Terai $(210 \mathrm{~m})$ were purposively selected for the study. It was found that in both of the sites for five years, although the years were not the same, there was a rise in change of $\mathrm{T} \max$ whereas for $\mathrm{T}$ min there was a rise for six years in Kanaki and three years in Dhangadhi. In both the sites, there was rise of change in average $\mathrm{T}$ max and $\mathrm{T} \min$. For the total rainfall also same pattern was observed as was followed in T max. Similarly, a change in average rainfall was recorded for five years in both the sites. Number of rainy days in both the sites was found decreased for six years, however, average change in total number of rainy days in Kakani was found increased while in Dhangadhi it was decreased (Paudel, 2015).

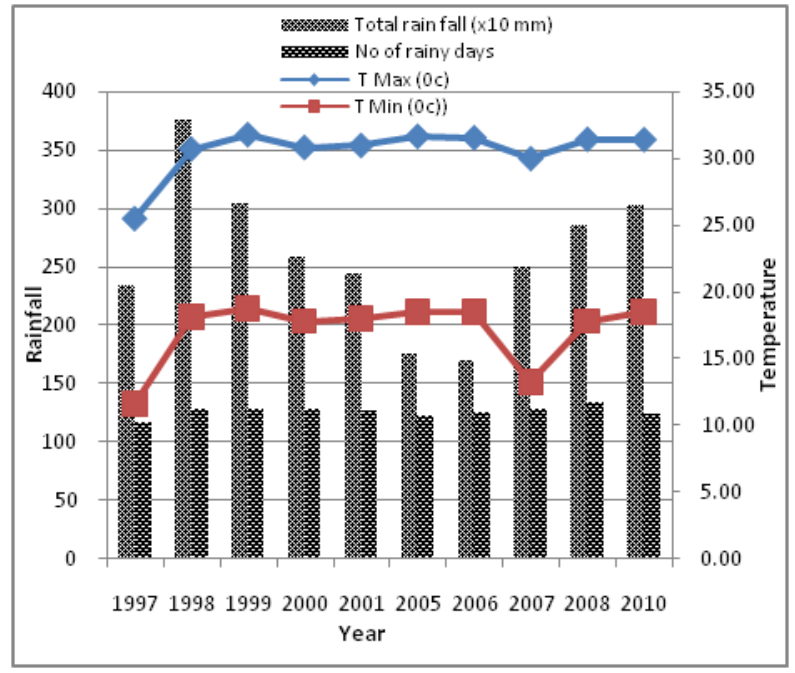

Fig. 2. Ten years' meteorological data of Kakani (2030m), Nepal (Paudel, 2015)

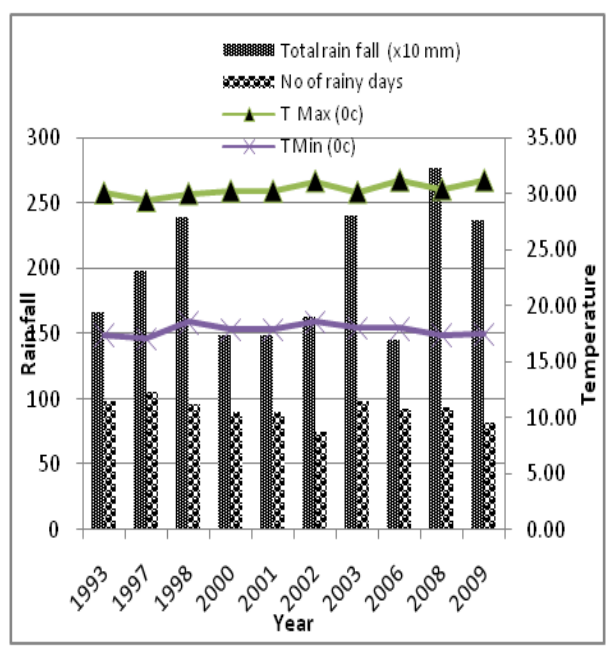

Fig. 3. Ten years' meteorological data of Dhangadhi $(210 \mathrm{~m})$, Nepal (Paudel. 2015)

From 10 years' meteorological observation in in the above sites of Kakani and Dhangadhi it was experienced that change in amplitude of maximum ( $\mathrm{T} \max$ ) and minimum ( $\mathrm{T}$ min) temperature were increasing in both sites of high hill and Terai. For total rainfall and 
number of rainy days in high hills site of Kakani is increasing while in Dhangadhi of far western Terai both the amount of rainfall and number of rainy days were recorded decreasing over the period. By inferring the date in the duration of the study it is concluded that that temperature and rainfall are affected in Nepal even in short span of 10 years. This clearly is evident that the impact of climate change in Nepal with respect to agriculture production and productivity might have been affected due to change in metrological parameters. Fluctuation in these parameters was more pronounced in Kakani than that of Dhangadhi. It implies that hills and mountains are more vulnerable to climate compared than that of Terai in Nepal.

\section{Climate change and global food security}

Repercussion of climate change in agricultural trade has grown dramatically in recent decades and now provides significant increments of national food supplies to major importing nations and substantial income for major exporting nations. These consequences have close links between agriculture and climate, the international nature of food trade and food security, and the need to consider the impacts of climate change in a global contextual of agriculture production system as a whole.

Climate change scenario with the use of compatible model predicted the greatest warming $\left(5.25^{\circ} \mathrm{C}\right.$ global surface air temperature increase), causes average national crop yields to decline almost everywhere up to $-50 \%$ in Pakistan (Rosenzweig, et al; 1993). Key factors in agricultural productivity are technological advances such as improved crop varieties and irrigation systems, and weather. Among these entities climate possess prime impact on agriculture systems. For example, weak monsoon rains in 1987 caused largely reduced crop production in India, Bangladesh, and Pakistan, contributing to reversion to wheat importation by India and Pakistan (World Food Institute, 1988). So was the case in 1980s which also saw the continuing deterioration of food production in Africa due to persistent drought and low production potential of crops due to negative impact of climatic factors in agriculture production. This resulted that international relief efforts were implied to prevent widespread famine in Africa. In the model, assuming that full agricultural trade liberalization and no climate change by 2020 provides for more efficient resource use. The prediction leads to a $3.2 \%$ higher value added in agriculture globally and $5.2 \%$ higher agricultural GDP in developing countries (excluding China) by 2060 compared to the original reference scenario. This policy change results in almost $20 \%$ fewer people at risk from hunger. If this scenario continues global cereal production increases by 70 million metric tons with most of the production increases occurring in developing countries (Rosenzweig, et al; 1993). Under such circumstances losses in production are greater in developing countries and at the same time, price increases are reduced slightly from what would occur without full trade liberalization, and the number of people at risk from hunger is reduced by about 100 million. The effect of climate change on these trends is generally 
to reduce production, increase prices, and increase the number of people at risk from hunger. However, it is observed in the model that developed countries increase cereal production in these scenarios even with the projected lower economic growth rates, but developing countries decrease production under all climate change scenarios.

The effect of temperature and precipitation trends on the yields of maize, rice, wheat and soybeans is shown in Table 2 (Don Hofstrand, 2011). The impact on yields is greater for temperature than for precipitation. The greatest yield impact of temperature was on wheat followed by maize. When the three percent yield gain from elevated $\mathrm{CO}_{2}$ levels is added to wheat, soybeans and rice, the yield response for rice and soybeans become positive but remained negative for maize and wheat. It is the explicit evidence that climate change has negative effect on global food production.

Table 2. Estimates of global impacts of temperature and precipitation trends on yields of four major crops, 1980-2008(Source: Don Hofstrand, 2011)

\begin{tabular}{|c|c|c|c|c|c|c|}
\hline Crop & $\begin{array}{l}\text { Global } \\
\text { production } \\
(1998-2002 \\
\text { Average million } \\
\text { metric tons })\end{array}$ & $\begin{array}{l}\text { Global yield } \\
\text { impact } \\
\text { temperatures } \\
\text { trends }\end{array}$ & $\begin{array}{l}\text { Global yield } \\
\text { of impact } \\
\text { precipitation } \\
\text { trends }\end{array}$ & of Subtotal & $\begin{array}{l}\text { Global } \\
\text { impact of } \\
\mathrm{CO}_{2} \text { trends }\end{array}$ & $\begin{array}{l}\text { yield } \text { Total } \\
\text { Change }\end{array}$ \\
\hline Maize & 607 & $\begin{array}{l}-3.1 \% \\
(-4.9 \%,-1.4 \%)\end{array}$ & $\begin{array}{l}-0.7 \% \\
(-1.2 \%, 0.2 \%)\end{array}$ & $\begin{array}{l}-3.8 \% \\
(-5.8 \%, \\
1.9 \%)\end{array}$ & $-0.0 \%$ & $-3.8 \%$ \\
\hline Rice & 591 & $\begin{array}{l}0.1 \\
(-0.9,1.2)\end{array}$ & $\begin{array}{l}-0.2 \\
(-1.0,0.5)\end{array}$ & $\begin{array}{l}-0.1 \\
(-1.6,1.4)\end{array}$ & 3.0 & 2.9 \\
\hline Wheat & 586 & $\begin{array}{l}-4.9 \\
(-7.2,-2.8)\end{array}$ & $\begin{array}{l}-0.6 \\
(-1.3,0.1)\end{array}$ & $\begin{array}{l}-5.5 \\
(-8.0,-3.3)\end{array}$ & 3.0 & -2.5 \\
\hline Soybean & 168 & $\begin{array}{l}-0.8 \\
(-3.8,1.9)\end{array}$ & $\begin{array}{l}-0.9 \\
(-1.5,-0.2)\end{array}$ & $\begin{array}{l}-1.7 \\
(-4.9,1.2)\end{array}$ & 3.0 & 1.3 \\
\hline
\end{tabular}

\section{Coping mechanisms to address effect of climate change in Nepal}

Nepal is rich in biodiversity and so is the case of climate that are prevailed almost all the climate available in the world, hence called the micro-museum of world climate. Climatic zones range from tropical to tundra with a narrow band of altitude. Climate varies from subtropical to arctic, all within a distance of approximately 180 kilometers. The broad differentiation in climate is that there is a great variety of micro climatic conditions, resulting in a diversity of land use and land practices within the country. In each of broad agroclimatic zone there is variation of land type, vegetation and cropping patterns. In general, the climate of the Terai, Dun valleys, and part of the Siwaliks (300-1000m) is subtropical while the climate of the middle mountains $(1000-3000 \mathrm{~m})$ ranges from warm temperate to cool temperate, and the high mountains $(2600-4200 \mathrm{~m})$ from cool temperate to 
sub-alpine. Mid hills or the mountain region is pleasant and amicable for many flora and fauna. As a result, this region is densely populated by many ethnicities. The Himalayas are above $4200 \mathrm{~m}$ and is represented by tundra and high alpine climate.

In view of climate sensitive agriculture, farmers need timely information on weather and climate variability to adjust their farming practices to minimize adverse impacts on rural livelihoods, and food security (http://www.worldbank.org/en/news). The economies of developing countries depend heavily on climate-sensitive sectors such as agriculture, forestry, fisheries, water supply, and other natural resources (Paudel, 2012). It is imperative that climate change adaptation is not separated from other priorities but is integrated into development planning, programs, and projects (World Bank, 2008). FAO (2008) underlined the need to think of food, energy and climate as one interconnected issue. Thus, to save the world from impending climate catastrophe through mitigation viz; direct reduction of greenhouse gases and their offsets and adaptation viz; support towards adapting to the effects of climate change, are available options to be implemented in the immediate future. Of the several options, Nepal can select adaptation options based on hazard specificity and location specific preferences. FAO (2009) has provided practices to cope with climate change hazards, such as rain water harvesting and soil moisture conservation, slope stabilization and management, management of high/low temperature stress, crop diversification, community based seed production of staple crops, resource conservation, and cultivation of stress tolerant crop varieties. In Nepal, more than $90 \%$ of the population is dependent upon the land for fulfilment of their basic needs (food, fodder, fuel, fiber and timber). Anthropogenic causes such as deforestation, overgrazing, and unscientific farming on steep slopes of Nepal and other developing countries have resulted in loss of flora and fauna, and have caused soil erosion, landslides in the hills, and flooding in the plain areas as well.

Of the many adoptive practices of coping adverse effect of climate change, Slope Agriculture Land Technology (SALT) is one of the practices identified for promotion (FAO, 2009). Slope land management by plantation of fodder trees and appropriate crops such as citrus, tea and coffee on terrace to control erosion should be promoted in the midhills. Important option prioritized to stabilize the slopes is the hedge row planting. The alleys not occupied by permanent crops should be planted alternately to cereals such as corn, upland rice, cotton, fruits, vegetables, and legumes, etc. This cycle of cropping provides the farmers with several harvests throughout the year. The intervention would identify best suitable model for the mid-hill region.

Other viable and practical practices of adoption with respect to climate change on agriculture could be tunnel/plastic house farming and off season vegetable cultivation and community centered small scale fruit (apple, apricot, walnut, and mandarin orange), 
vegetable, and potato seed storage and so on. Hence, priority should be given for the development of localized tunnel farming technology by using new ways and techniques that are being practiced along north- south road accessible areas in the mid-hills from east to west of the country. Localized tunnel cultivation systems are sustainable and cause low environmental pollution to agriculture systems, in addition to reducing the high/low temperature risks that make income generation from off season production of vegetables; viz., tomato, cole crops (crops belonging to cruciferous family). Based on climatic suitability, rice, wheat, legumes and oilseeds are the major commodities of the Terai. Rice, maize, wheat, pulses and oilseeds are major commodities in the hills. And potato, barley, wheat, buckwheat, amaranth, and different millets are the commodities suitable for the mountains where these are being grown from time immemorial in Nepal. It has been established that quality seed alone can increase crop yields up to 10-25\%. Seed production groups for important food crops (rice, maize, wheat, barley, millet) have shown encouraging results in many parts of the country. Improved seed produced by users' groups in a community based concept has helped increased crop production. This practice is one of the coping measures to mitigate climate change effect by availing quality seed to local communities. Along with other resource-conserving farming practices, conservation agriculture can improve rural incomes and livelihoods by reducing production costs, managing agro- ecosystem productivity, encouraging diversity for more sustainably, and minimizing unfavorable environmental impacts, especially in small and medium-scale farms.

\section{Adoption mechanisms to address climate change in Nepal}

In the climate sensitive agricultural sector, farmers need timely information on weather and climate variability to adjust their farming practices and minimize adverse impacts on

rural livelihoods, agricultural productivity and food security (http://www.worldbank.org/en/news). Nepal, compared to her geographical size, encompasses a wide range of physiographic regions, ecosystems and vegetation from flat lowlands to steep mountain slopes which is endowed with $0.1 \%$ of earth's land mass and harbors $2.2 \%$ of flowering plants, $1.4 \%$ of reptiles, $2.2 \%$ of fishes, $8.5 \%$ of birds, $4.2 \%$ of butterflies and $4 \%$ of mammals of the world (BPP, 1995). The country has high levels of biodiversity. Nepal is rich in agrobiodiversity having diversity of agro-ecological zones and farming systems (Gauchan and Shrestha, 2015). Because of such a varied agroecological dimension with respect to climate, flora and fauna Nepal is the $10^{\text {th }}$ richest country for agricultural biodiversity in Asia. She has 7000 flowering plant species that makes her one of the global hotspots for both natural and agricultural biodiversity. Among them 370 species are endemic and about 600 food-plants species have been estimated to be grown within the altitude range of $60 \mathrm{~m}$ to $4200 \mathrm{~m}$ above sea level (MoFSC, 2002; Upadhyay and Joshi, 2003). 
Nepal is blessed with diverse climate conditions ranging from $60 \mathrm{~m}$ to $8,848 \mathrm{~m}$, the top of the world, despite this boon in Nepal, climate change has shown impacts on many indigenous breeds of animals and varieties of crops which are in the verge of extinction. These flora and fauna of plants and animals have been boon for the resource poor populace of Nepal. They include many indigenous crop species of aromatic rice: Basmati, Thapa Chini, Kalanamak, Jhinuwa, Kanak Jira, Chananchura, Tunde Masino, Anandi (red and white), many local varieties of rice (Ghaiya, Jundi, Marshii), wheat, maize (Sathiya, Murali, Dhinde, Sete, Panheli), finger millet (Okhle, Dalle, Paundure, Jhapre, Mutthe,Samdhi), buck wheat (bitter, sweet, Chuchhe, Bharule, bhate), many grain legumes, vegetable legumes, and other minor crops (foxtail millet, sorghum, naked barley, Panicum millet, Aamaranthus, proso millet (white, yellow). Similarly, for animals including buffalo (Parkote, Lime), cattle (Yak and Lulu of high hills), Achhamigai (smallest cow recorded in the world), goat (Chyangra for Pasmina wool), Bhyanjlung of sheep (carpet wool production), goat (Khari, Sinhal,), Bampudke Sungur (native pig), Sakhini Kukhura (native fowl), and many other unrecorded species of crops and animals are endangered. There is a need to conserve such very important genetic materials which are becoming endangered due to the effect of climate change.

A number of adoptive strategies have been applied to address consequences of climate change in agriculture in Nepal. Paudel (2012) has highlighted released of drought tolerant varieties of rice, wheat, maize and legumes. These varieties can withstand drought and can yield even in some fluctuation of moisture which should not be limiting production under stress environment. Rice in Nepal is mostly under transplanted condition, however, drought tolerant cultivars could be cultivated as direct seeding when the rainfall is unpredicted and there are very slim chances of cultivating transplanted rice as a result of change in rainfall patterns. On the other hand, varieties that can withstand submerged condition have also been released by the research such as SwornaSub-1, IR-64, and Sanwa Mansuli are introgressed containing sub-1 gene which is submergence tolerant. It has been reported that up to 17 days of complete submergence could tolerate by Swarna Sub-1 rice variety under submerged condition. For high hill and temperate conditions $(2500 \mathrm{~m}$ and above) cold tolerant rice varieties of Chandannath-1 \& 3 and other have been developed and popularized especially in Jumla and Karnali regions (Paudel, 2011) where there is acute shortage of food and around 3.9 million people in the area suffered from hunger and malnutrition (Paudel, 2010). Similarly, rice varieties Machhapuchhere-3 and Chhomrong Local have been popularized in upper high hills of more than 2000m (Karki, et al; 2010). Likewise, improved varieties of maize, wheat, maize, tomato and potato have been developed to address situation brought about by climate change such as emergence of new insects, pests and diseases and natural disasters of flood, drought, hail storm and many more. All of such negative consequences of climate change are not sufficiently addressed thereby efforts to limit these consequences of climate change on agriculture should 
immediately be taken into consideration in the highly vulnerable country like Nepal. Aside from releasing different varieties of crop, Nepal Agricultural Research Council (NARC) has recommended technologies to address vagaries of climate change (Paudel, 2012); these include resource conservation technologies of zero tillage, bed planting, permanent bed planting, strip tillage, minimum tillage, surface seeding, crop residue management and so on and so forth. There are composite technologies to address the effects of climate change on agriculture; these include gray leaf spot disease management of maize by growing resistant varieties. The crop husbandry technologies to mitigate adverse effect of climate change are early planting and wide spacing, balanced use of chemical fertilizers and integrated nutrient management, integrated pest management, and selective application of pesticides.

Important cereals of rice, maize and wheat yields in warm environments can be raised significantly by modifying agronomic practices of timely planting, incorporating residues and following appropriate crop rotations as proved beneficial in resource conservation techniques. Clearly crops of rice, wheat and maize yield in lower latitudes may decrease due to global warming, and may be further affected by water scarcity or drought. One approach to dealing with these heat-related constraints is to improve germplasms of these crops to provide higher tolerance to stresses associated with changed environments. Hence, new varieties screened by Nepal Agriculture Research Council (NARC) should be demonstrated to farmers focusing on enhancing the crop yield potential and to maintain yield under stress and fluctuation of temperatures. In this way, they will assist in building cropping systems resilience to the global warming and natural hazards that could jeopardize the livelihood of resource-poor farmers who depend on the harvest of these crops.

\section{Conclusion}

It has already been highlighted that there are ample opportunities to address negative effect of climate change in Nepal so far as agriculture is concerned. There are many a more alternatives to address issues of climate change with respect to agriculture in Nepal. Consequences of all climatic phenomena have resulted food and nutritional shortage in Nepal. Adaptation and mitigation are the available tools to address effect of climate change in agriculture and livelihood maintenance. Nepal is in the grip of climate change, however, there is very little to do with mitigation as Nepal does not emit significant quantity of greenhouse gases and the only way is the adaptation to cope up with effect of climate change. Development of crop varieties and animal breeds to address climate change concerns through adoption mechanisms are the only ways to lessen negative effect of climate change in agriculture. In this regard, agriculture research systems of Nepal has developed and maintained crop varieties and animal breeds to address climate change and such technologies have been popularized in the agro-ecological niches wherever feasible. 
This has helped, to some extent, sustain food security, and enhance livelihood in Nepal as well. Policy related to address negative issues of climate change in agriculture in Nepal should be through adoption mechanisms. Alternatives available within the country should be harnessed effectively to tackle vulnerability brought about by the impact of climate change affecting adversely on food and nutritional security of Nepal in a way livelihood of Nepalese is maintained in changed scenario of climate change in general and agriculture in particular.

\section{References}

Bartlett, R; L Bhattarai; D Pant., H Hosterman; and P McCornick,. 2010. Climate change impacts and adaptation in Nepal. Colombo, Srilanka: International Water Management Institute, 35p. (IWMI Working paper 139). Doi:10.5337/2010.227.

Bates, BC; ZW Kundzewicz; S Wu; and JP Palutikof (eds.). 2008. Climate change and water. Technical paper on the intergovernmental panel on climate change. IPCC secretariat, $210 \mathrm{p}$.

Don, Hofstrand. 2011. In http://www.agmrc.org/renewable_energy/agmrc-renewableenergy-

newsletter/?climate_change_beginning_to_impact_global_crop_production\&show=art icle\&articleID=613\&issueID=118. Retrieved on 29 Sep 2014.

FAO. 2009. Climate change impacts on agriculture and food security and disaster risk management as entry point for climate change adaptation.http://www.fao. org/docs/up/easypol/778/climate-change_impacts_

on_agric_food_security_slides_077EN.pdf.

FAO. 2008. Climate change adaptation and mitigation: challenge and opportunity for food security.http://www.fao.org/docrep/fao/meeting/013/k2545e.pdf.

Gauchan, D and S Shrestha. 2015. Agricultural and Rural Mechanization in Nepal: Status, Issues and Options for future. Proceedings of the workshop on Rural Mechanization: Policy and Technology Lessions from Bangladesh and other Asian Countries, 7-8 March, 2013 Dhaka, Bangladesh.

http://www.irinnews.org/country/npa/nepal. Retrieved on Sep 6, 2014.

http://www.worldbank.org/en/news. Retrieved on 7 Sep 2014.

https://unfccc.int/files/adaptation/application/pdf/nepal_summary_cca.pdf

IBSNAT (International Benchmark Sites Network for Agrotechnology Transfer). 1989.

Decision Support System for Agrotechnology Transfer Version 2.1 (DSSAT V2. 1). Honolulu: Dept. of Agronomy and Soil Science. College of Tropical Agriculture and Human Resources: University of Hawaii as cited by Rosenzweig, C., M. L. Parry, G. Fischer, and K. Frohberg. 1993. In Climate change and world food supply. Research Report No. 3. Oxford: University of Oxford, Environmental Change Unit. 
Karki, TB; KB Koirala; and SB BK. 2010. Participatory variety selection of cold tolerant rice in the western hills of Nepal, Agronomy Journal of Nepal 1:74-79.

Malla, G. 2008. Climate change and its impact on Nepalese agriculture. Journal of Agriculture and Environment 9:62-71.

MoFSC (Ministry of Forestry and Soil Conservation). 2002. Nepal biodiversity strategy, His Majesty's Government, Nepal.

NARC (Nepal Agricultural research Council).1987-1998.Annual Reports, Kathmandu: Nepal Agricultural Research Council. NATWGs. 2010. InPaudel, M.N. 2012. Adaptation mechanisms in agriculture for climate change in Nepal. Hydro Nepal, Special issue, April 2012, 82-85.

Paudel, MN. 2010. Effect of climate change on food production and its implication in Nepal. Agronomy Journal of Nepal, 1:40-49.

Paudel, MN. 2011. Rice cultivation in the highest elevation in the world. Agronomy Journal of Nepal 2:31-41.

Paudel, MN. 2012. Adaptation mechanisms in agriculture for climate change in Nepal. Hydro Nepal, Special issue, April 2012, 82-85.

Paudel, MN. 2015. Global effect of climate change and food security with respect to Nepal. The Journal of Agriculture Environment, 16:1-20.

Regmi, HR. 2007. Effect of unusual weather on cereal crops production and household food security', Journal of Agriculture and Environment 8:20-29.

Rosenzweig, C; ML Parry; G Fischer; and K Frohberg. 1993. Climate change and world food supply. Research Report No. 3. Oxford: University of Oxford, Environmental Change Unit.

Sherpa, A. 2010. Campaign ambassador speaks Mr. Apa Sherpa', Climate for Life: A Call from the Himalayas (World Wildlife Fund). URL: http://climate4life.org/ thecampaign/campaign-ambassadors/apa-sherpa. html.

Shrestha, M. 2009. Everest hosts Nepal cabinet meeting, CNN (Cable News Network, USA). URL: http:// articles.cnn.com/2009-12-04/world/everest.cabinet. meeting_1.

Upadhaya, MP and BK Joshi. 2003. Plant Genetic Resources in SAARC Countries: Their Conservation and Management: Nepal Chapter. SAARC Agriculture Information Centre. pp.297-422.

World Food Institute. 1988. World Food Trade and U.S. Agriculture, 1960-1987. Ames: Iowa State University.Retrieved on 16 July 2013. 